------Jou. Raf. Sci., Vol. 20, No.4 pp 82-95, 2009------

\title{
Estimation of Net Radiation in Iraq
}

\author{
Waleed I. Al- Rijabo \\ Department of Physics \\ College of Education \\ Mosul University
}

\author{
Rajaa A. Basheer Amal M. Banoosh \\ Department of Physics \\ College of Science \\ Mosul University
}

(Received 20 / 4 / 2009 ; Accepted 5/10 / 2009)

\begin{abstract}
FAO-56 Model was used to estimatenet Net Radiation falling on horizontal surface in Mosul, Baghdad and Nasiriyah stations for the time series (1980-2002). Results showed that there is a sort of relatedness between estimated and measured incoming short wave radiation(Rs) in the three stations, where the values of mean absolute error (M.A.E.) is not exceed $(11,14,24) \%$ in Baghdad, Nasiriyah and Mosul respectively. Rn estimated by the Model appear that Mosul station gives the lowest values of $\mathrm{Rn}$ in comparison with Baghdad and Nasiriyah stations, this is due to the amount of incoming solar radiation reached the earth surface. Summer months in Nasiryiah gave also values of Rn lower than that in Baghdad because of the sand storm which domain during the summer months in Nasiriyah. Two linear Regression Equations were found, the first between net radiation and net incoming short wave radiation (Rn \& Rns ) and the second between net radiation and net long wave radiation ( $\mathrm{Rn} \& \mathrm{Rnl}$ ) in each of the three stations. The correlation coefficient (R) found in the first relation is very high and ranged between $(0.98-0.99)$, while the values of $(\mathrm{R})$ in the second relation ranged between $(0.67-0.87)$. Liner Regression Equations were also found between Rn and meteorological elements (Temperature, Relative Humidity, wind Speed and Sun Shine Ratio ) in each of the three stations.

$$
\begin{aligned}
& \text { تخمين صافي الإشعاع في العراق } \\
& \text { الملخص } \\
& \text { تم استخدام النموذج الرياضي FAO-56 لتخمين محصلة الإثعاع الثمسي الساقط على السطح الأفقي }
\end{aligned}
$$

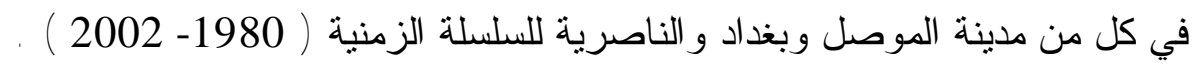

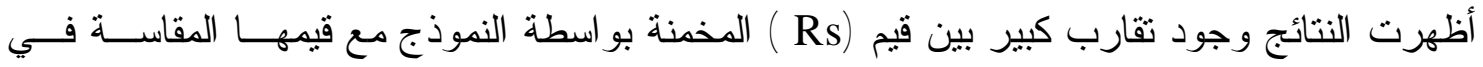

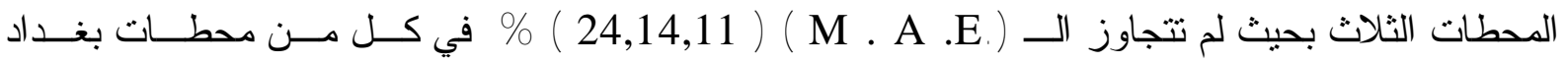

$$
\begin{aligned}
& \text { و الناصرية و الموصل على النوالي. Rn الني نم الحصول عليها بواسطة النموذج أظهرت ان محطة الموصل }
\end{aligned}
$$

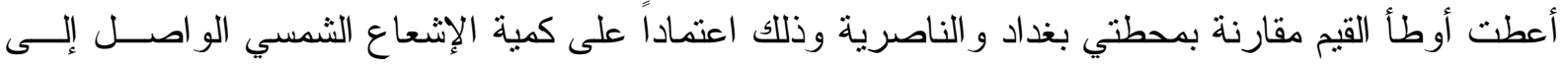

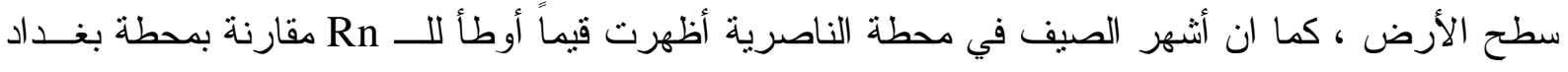

$$
\begin{aligned}
& \text { وذللك بسبب العواصف الرملية التي تسود خلال أثنهر الصيف في الناصرية. }
\end{aligned}
$$




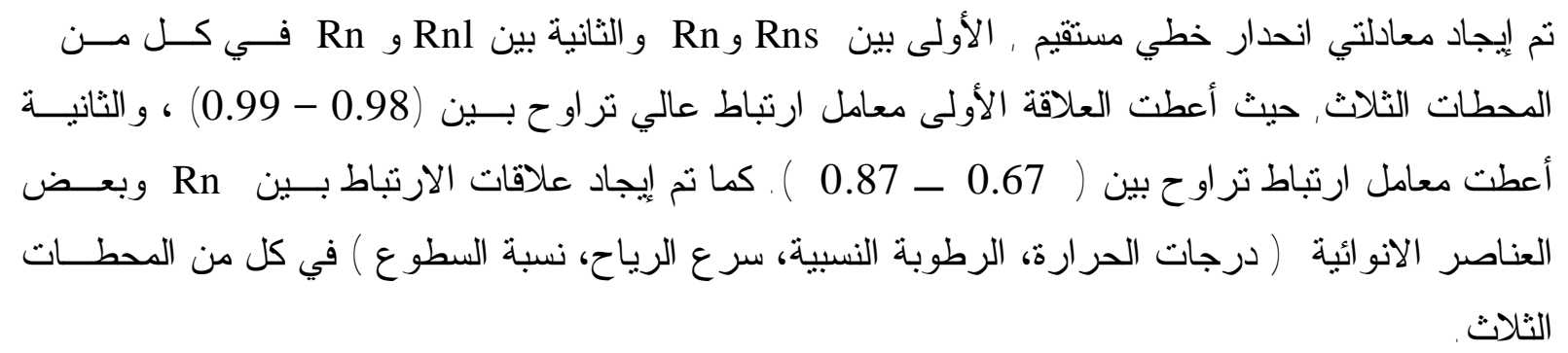

\section{INTRODUCTION}

The determination of earths radiation budget is essential for atmospheric medeling, climatic studies and for estimating reference crop evapotrnspiration (Steven and Knot, 2003; Alados et al., 2003 ).

The net radiation $(\mathrm{Rn})$ is the difference between incoming and outgoing radiation of both short and long wave lengths, so it represent the balance between the energy absorbed ,reflected and emitted by the earth surface (Kjaersgraard, 2007).

$(\mathrm{Rn})$ is normally positive during the day time and negative during the night time. The total daily value for $(\mathrm{Rn})$ is almost positive over a period of 24 hours, except in extreme conditions at high latitudes (FAO 56 ).

Incoming short wave radiation (Rs) have wave lengths ranged between ( $0.15-3)$ micron and depend on: daytime hours, latitudes, season, thickness of the atmosphere, aerosols, clouds, water vapor and air molecules (Eric et al.,2003; Limia, 2005).

The outgoing short wave radiation is function of incoming solar radiation and the bulk surface albedo. The net incoming short wave radiation ( Rns) represent the difference between the incoming and outgoing short wave radiation. The incoming long wave radiation depend on sky temperature and sky emissivity. The sky emissivity is a summary effect of all layers of the atmosphere which depend on cloud cover, humidity and temperature structure(Roger and Barry, 2003; Richard, 1997).

The outgoing long wave radiation depend on surface emissivity and surface temperature. The difference between the outgoing and incoming long wave radiation represent the net long wave radiation $(\mathrm{Rn} \mathrm{l})$.

Almost the outgoing long wave radiation is greater than the incoming long wave radiation , So the (Rnl) represent energy losses.

In many biological, agronomic and engineering applications, $\mathrm{Rn}$ is required rather than total solar radiation (Dong et al., 1992).

Many attempt have been made to relate $\mathrm{Rn}$ to Rs, air temperature, and other variables such as relative humidity and extraterrestrial radiation (Irmak et al.,2003; Offerle and Grimmond, 2003).

Nearly all the meteorological stations in Iraq haven't net radiometers instruments, so we use the FAO model which is widely used for predicting Rn .

There locations in Iraq (Mosul, Baghdad, Nasiriyah) were used to study the net radiation during the period (1980 - 2002), where Mosul represent the northern part of Iraq, Baghdad represent the middle part of Iraq and Nasiriah represent the southern part of Iraq . 


\section{METHODOLOGY}

FAO - 56 Model were used to determine the different components of solar radiation and long wave radiation .Extraterrestrial radiation $(\mathrm{Ra})$ in $\left(\mathrm{MJ} \mathrm{m}^{-2}\right.$ day $\left.{ }^{-1}\right)$ were calculated from the following formula :

$$
\operatorname{Ra}=\frac{24(60)}{\pi} \operatorname{Gsc} d r[w s \sin (\varnothing) \sin (\delta)+\cos (\varnothing) \cos (\delta) \cos (w s)]
$$

where:

$$
\begin{aligned}
\text { Gsc } & =\text { solar constant }\left(0.082 \mathrm{MJm}^{-2} \mathrm{~min}^{-1}\right) \\
\mathrm{dr} & =\text { inverse relative distance Earth }- \text { Sun } \\
\text { ws } & =\text { sunset hour angle }(\mathrm{rad}) \\
\varnothing & =\text { latitude }(\mathrm{rad}) \\
\delta & =\text { solar declination }(\mathrm{rad})
\end{aligned}
$$

The inverse relative distance Earth-Sun (dr)and solar declination $(\delta)$ are given by :

$$
\begin{gathered}
\mathrm{dr}=1+0.033 \cos [2 \pi \mathrm{J} / 365] \\
\delta=0.409 \sin \left[\frac{2 \pi}{365} \mathrm{~J}-1.39\right]
\end{gathered}
$$

Where $\mathbf{J}=$ number of the day in the year

The sunset hour angle (Ws) is given by:

$$
\mathrm{Ws}=\operatorname{arcos}[-\tan (\varnothing) \tan (\delta)]
$$

The day light hours $(\mathrm{N})$ are given by:

$$
\mathrm{N}=\frac{24}{\pi} \mathrm{Ws}
$$

The incoming short wave radiation (Rs) is given by:

$$
\mathrm{Rs}=[0.25+0.5 \mathrm{n} / \mathrm{N}] \mathrm{Ra}
$$

Where $\mathrm{Rs}$ is in $\left(\mathrm{MJ} \mathrm{m}^{-2}\right.$ day $\left.^{-1}\right)$ and $\mathrm{n} / \mathrm{N}$ is a relative sunshine duration The net short wave radiation (Rns) resulting from the balance between incoming (Rns) and reflected solar radiation is given by:

$$
\operatorname{Rns}=(1-\alpha) \operatorname{Rs}
$$

Rns and $\mathrm{Rs}$ are in $\left(\mathrm{MJ} \mathrm{m}^{-2}\right.$ day $\left.^{-1}\right), \alpha$ is the albedo .

The net outgoing long wave radiation $(\mathrm{Rn} 1)$ in $\left(\mathrm{MJ} \mathrm{m}^{-2}\right.$ day $\left.^{-1}\right)$ is given by : 


$$
\mathrm{Rnl}=\sigma\left[\frac{\mathrm{T} \max , \mathrm{K}^{4}+\mathrm{Tmin}, \mathrm{k}}{2}\right](0.34-0.14 \sqrt{\text { ea }})\left(1.35 \frac{\mathrm{Rs}}{\mathrm{Rso}}-0.35\right) \ldots . .(8)
$$

Where :

$$
\sigma=\text { Stefan-Boltzman constant }\left(4.903 \times 10^{-9} \mathrm{MJ} \mathrm{K}^{-4} \mathrm{~m}^{-2} \text { day }^{-1}\right)
$$

Tmax $=$ maximum absolute temperature during $24-$ hour period

Tmin $=$ minimum absolute temperature during 24-hour period

ea $=$ actual vapour pressure $(\mathrm{kpa})$

$\mathrm{Rs} / \mathrm{Rso}=$ relative short wave radiation

$$
\text { Rso }=\text { clear sky radiation }\left(\mathrm{MJ} \mathrm{m}^{-2} \text { day }^{-1}\right)
$$

Rso is given by the following formula:

$$
\text { Rso }=\left(0.75+2 \times 10^{-5} \quad \mathrm{Z}\right) \mathrm{Ra}
$$

Where $\mathrm{Z}=$ station elevation above sea level (m).

The net radiation $\mathrm{Rn}$ is the difference between the incoming net short wave radiation and Rns and the outgoing net long wave radiation $\mathrm{Rn} 1$ :

$$
\mathrm{Rn}=\mathrm{Rns}-\mathrm{Rn} 1
$$

Three meterological station (Mosul, Baghdad and Nasiriyah) were used to test this model.

\begin{tabular}{|c|c|c|c|}
\hline Stations & Latitude & Longitude & Altitude (m) \\
\hline Mosul & $36^{\circ} 19^{\prime}$ & $43^{\circ} 09^{\prime}$ & 223 \\
\hline Baghdad & $33^{\circ} 14^{\prime}$ & $44^{\circ} 14^{\prime}$ & 32 \\
\hline Nasiriyah & $31^{\circ} 05^{\prime}$ & $46^{\circ} 14^{\prime}$ & 3 \\
\hline
\end{tabular}
The latitude, longitude, altitude and years of observations for these stations were presented in table (1).

Table 1: The geographical informations of the three stations (Mosul, Baghdad, and Nasiriyah ) For the time series(1980-2002).

The mean monthly metrological elements (Tmax, Tmin, Tmean, Rs, Sunshine duration (n), Relative Humidity, Wind Speed, Maximum Possible Sunshine (N), Sunshine Ratio) for the three stations were presented in the appendix $(1,2,3)$.

The mean monthly values of radiation elements ( $\mathrm{Ra}, \mathrm{Rso}, \mathrm{Rns}, \mathrm{Rnl}$ and $\mathrm{Rn}$ ) were estimated using the FAO56 model and presented in the appendix (4, 5, 6 ).

Mean Absolute Error Was used to show the deviations between the measured and estimated values of Rs in the three stations, where : 
M.A.E. $=\frac{1}{\mathrm{n}} \sum_{1}^{\mathrm{n}}\left|\frac{\mathrm{Gi}-\mathrm{Fi}}{\mathrm{Fi}}\right|$

$\mathrm{Gi}=$ estimated values, $\mathrm{Fi}=$ measured values (Bodescu-1988).

Comparison between the mean monthly values of $\mathrm{Rn}$ in the three stations were performed . Correlations between $\mathrm{Rn}$ and radiation elements ( Rs, Rns, Rnl ) were found in the three stations.

Correlations between Rn and different metrological elements (Temp., RH, wind speed and $\mathrm{n} / \mathrm{N}$ ) were found also.

\section{RESULTS AND DISCUSSION}

\section{Comparison between measured and estimated values of incoming short wave radiation $(\mathbf{R s})$ :}

The values of (Rs) estimated by Model and that measured by the actinography in Mosul, Baghdad and Nasiriyah stations during the months of the year were presented by table (2) .

Table 2: Mean monthly values of estimated and measured Rs in Mosul, Baghdad and Nasiriyah stations in ( $\left.\mathrm{MJ} / \mathrm{m}^{2} . \mathrm{d}\right)$.

\begin{tabular}{|c|c|c|c|c|c|c|c|c|c|c|c|c|c|c|}
\hline Mor & & Jan. & Feb. & Mar. & Apr. & May & Jun. & July. & Aug. & Sep. & Oct & Nov & Dec & М.А.Е.\% \\
\hline \multirow{2}{*}{ Mosul } & Rs est. & 8.3 & 11.2 & 15.6 & 20 & 24.2 & 27.8 & 27.3 & 25.1 & 21.2 & 15.1 & 10.1 & 7.8 & \multirow{2}{*}{24} \\
\hline & $\begin{array}{c}\text { Rs } \\
\text { Mean }\end{array}$ & 6.6 & 9.5 & 12.1 & 16.3 & 19 & 21.4 & 21 & 19.7 & 17 & 12.2 & 8.4 & 6.2 & \\
\hline \multirow{2}{*}{ Baghdad } & Rs est. & 10.9 & 14.3 & 18.2 & 21.6 & 25 & 28.2 & 27.6 & 26 & 21.8 & 16.4 & 12.3 & 10.1 & \multirow{2}{*}{11} \\
\hline & $\begin{array}{c}\text { Rs } \\
\text { mean }\end{array}$ & 9.9 & 13 & 16.5 & 20.1 & 22 & 24.7 & 24.3 & 22.5 & 19.3 & 14.8 & 10.8 & 8.8 & \\
\hline \multirow{2}{*}{ Nasiriyah } & Rs est. & 11.6 & 14.8 & 18 & 12 & 23.4 & 24.9 & 24.8 & 23.8 & 21.4 & 16.9 & 12.8 & 10.7 & \multirow{2}{*}{14} \\
\hline & $\begin{array}{c}\text { Rs } \\
\text { mean }\end{array}$ & 9.9 & 12.9 & 15.9 & 19.4 & 20.8 & 21.6 & 21.8 & 20.5 & 18.8 & 15 & 10.4 & 9 & \\
\hline
\end{tabular}

From the table we can see a good agreement between the estimated and measured values of Rs specially in Baghdad and Nasiriyah.

The Mean Absolute Error found does not exceed (11, 14,24 )\% in Baghdad, Nasiriyah and Mosul respectively.

Linear regression equations between estimated and measured values of Rs were presented in fig. (1) for the three stations. The correlation coefficient found between the estimated and measured values were $(0.973,0.975,0.973)$ in Mosul, Baghdad and Nasiriyah respectively. This mean that their is a high correlations between the estimated and measured values of Rs. In our research we use the measured values of Rs for computing Rn because its available . 


\section{Evaluation of Net Radiation in Mosul, Baghdad and Nasiriyah stations.}

Fig.(2) show clearly that the net radiation $(\mathrm{Rn})$ in Mosul station is less than that in Baghdad and Nasiriyah, this is due to the amount of incoming short wave radiation received in Mosul is less than that in Baghdad and Nasiriyah .

The values of Rn during the summer months in Baghdad is higher than that in Nasiriyah, this is because of the dust storm during the summer months in Nasiriyah which affect greatly the amount of the incoming short wave radiation received on horizontal surface.

\section{Correlations between $\mathrm{Rn}$ and different solar radiation components}

Fig. (3) shows the liner regressions obtained between Rn and Rns in Mosul, Baghdad, Nasiriyah stations. The correlation coefficient found for these relations are $(0.98,0.99,0.99)$ in Mosul, Baghdad and Nasiriyah respectively. This indicated there is a highly correlations between Rn and Rns .

Fig. (4) Shows the correlations between Rn and Rnl in Mosul, Baghdad and Nasiriyah stations. The correlation coefficient in the three stations are variable and can be arranged according to there magnitude as $(0.87,0.77$, o.67) in Baghdad, Mosul and Nasiriyah respectively.

We can mentioned here that the values of $(\mathrm{R})$ is less that between $\mathrm{Rn}$ and Rns. Liner regression equations were also found between Rns and Rnl which are presented in fig.(5). A highly correlation coefficients were found for these relations which can be arranged according to their magnitude as $(0.91,0.87,0.75)$ for Baghdad ,Mosul and Nasiriyah station respectively .

\section{Correlations between net radiation and different meteorological elements}

Fig.(6) shows the correlations between the mean monthly values of obtained $\mathrm{Rn}$ and temperature in Mosul, Baghdad and Nasiriyah stations .

A highly positive correlations were found and the correlation coefficient are $(0.88$, 0.95,0.86) in Baghdad, Mosul, Nasiriyah .

Fig.(7) shows a highly negative correlations between the mean monthly values of $\mathrm{Rn}$ and relative humidity. The values of correlation coefficient found for these correlations are $(0.82,0.93,0.89)$ for Mosul, Baghdad and Nasiriyah stations respectively.

Fig.(8) shows a highly positive correlations between the mean monthly values of $\mathrm{Rn}$ and wind speed. The values of $(\mathrm{R})$ found for these correlations are $(0.89,0.89,0.87)$ for Mosul, Baghdad and Nasyriah stations respectively.

Fig.(9) show a positive correlations between the mean monthly values of $\mathrm{Rn}$ and sunshine ratio $(\mathrm{n} / \mathrm{N})$.

The correlations coefficients obtained are $(0.77,0.77)$ for Baghdad and Mosul stations respectively. Nasiriyah station did not give a good correlation between $\mathrm{Rn}$ and $\mathrm{n} / \mathrm{N}$.

The main conclusions are :

\section{CONCLUSION}

1. A good agreement has been found between estimated and measured values of Rs, where the value of $\mathrm{M}$. A . E. does not exceed (11, 14, 24 ) \% in Baghdad, Nasiriyah and Mosul stations respectively . 
2. The lower values of Rn was obtained in Mosul station in comparison with Baghdad and Nasiriyah. The summer months in Nasiryiah station gave values of Rn less than that in Baghdad, this is due to sand storm existing during these months in Nasiriyah.

3. Two Linear Regression Equations were found between ( $\mathrm{Rn}$ and $\mathrm{Rns}$ ) and (Rn and Rnl) in each of the three stations, which give relatively high correlation coefficients.

4. Linear Regression Equations has been found between $\mathrm{Rn}$ and other meteorological elements ( Temperature, Relative Humidity, Wind Speed, Sun Shine Ratio) in each of the three stations.

\section{REFERENCES}

Alados, I.; Foyo, I.; Olmo, Alados, L.(2003). Relationship between net radiation and solar radiation for semi-arid shrub-land. J. Agric. and Forest Met.,116, 221-227.

Bodescu, V. (1988). Comment on the statistical indicators used to evaluate the accuracy of solar radiation models. Solar Energy, 40 ( 5), 480-499.

Dong, A.; Grattan, S. R; Carroll, J.J. ; Drashar , C.R.K.(1992). Estimation of day- time net radiation over well watered grass. J. Irrig. Drain .Eng.118(3),466- 479.

Eric, W.; Danielson, J. L.; Elliot A. (2003). "Meterology ". 2nd edn. Published by Mc Graw - Hill company. 558p.

FAO-56 (1998). Crop evapotranspiration, guide lines for computing crop water requirement, FAO-Irrigation and Drainage paper . 300p.

Irmak, S.; Jones, J. W.; Irmak , A.; Howell, T.A. ; Jacobs, J.M; Allen , R.G. ; Hoogenboom, G, (2003). Predicting daily net radiation using minimum climatological data. $J$. Irrig.Drain.Eng.,129(4),256-269.

Kjaersgraard, J. (2007). Estimation of energy balance components for surfaces with low vegetation .Ph. D Thesis University of Copenhagen, Faculty of Life Scince, Denmark .

Lmia, M. F. (2005). Staudies on solar radiation in Mosul city, Msc- Thesis, University of Mosul - College of Education . Dept . of physics, Iraq.

Offerle, B. ; Grimmond, C. S. B. (2003), Parameterization of net all wave radiation for urban area . J. Applied Met., 42,1157-1173.

Roger, G.; Barry ; Richard (2003) . Atmosphere, weather and climate .8th edn., J. Chorley Route Ledge, Tayler and Francis group, 421p.

Richard, A. Anthes (1997). "Meteorology". 7th edn. By prentice Hall, Inc , 486p.

Steven , A. ; Ackerman ; John A. ;Knot (2003). "Meteorology Understanding the Atmosphere", Thomson Brooks/cole, 486 p. 
Waleed I. Al- Rijabo et al.

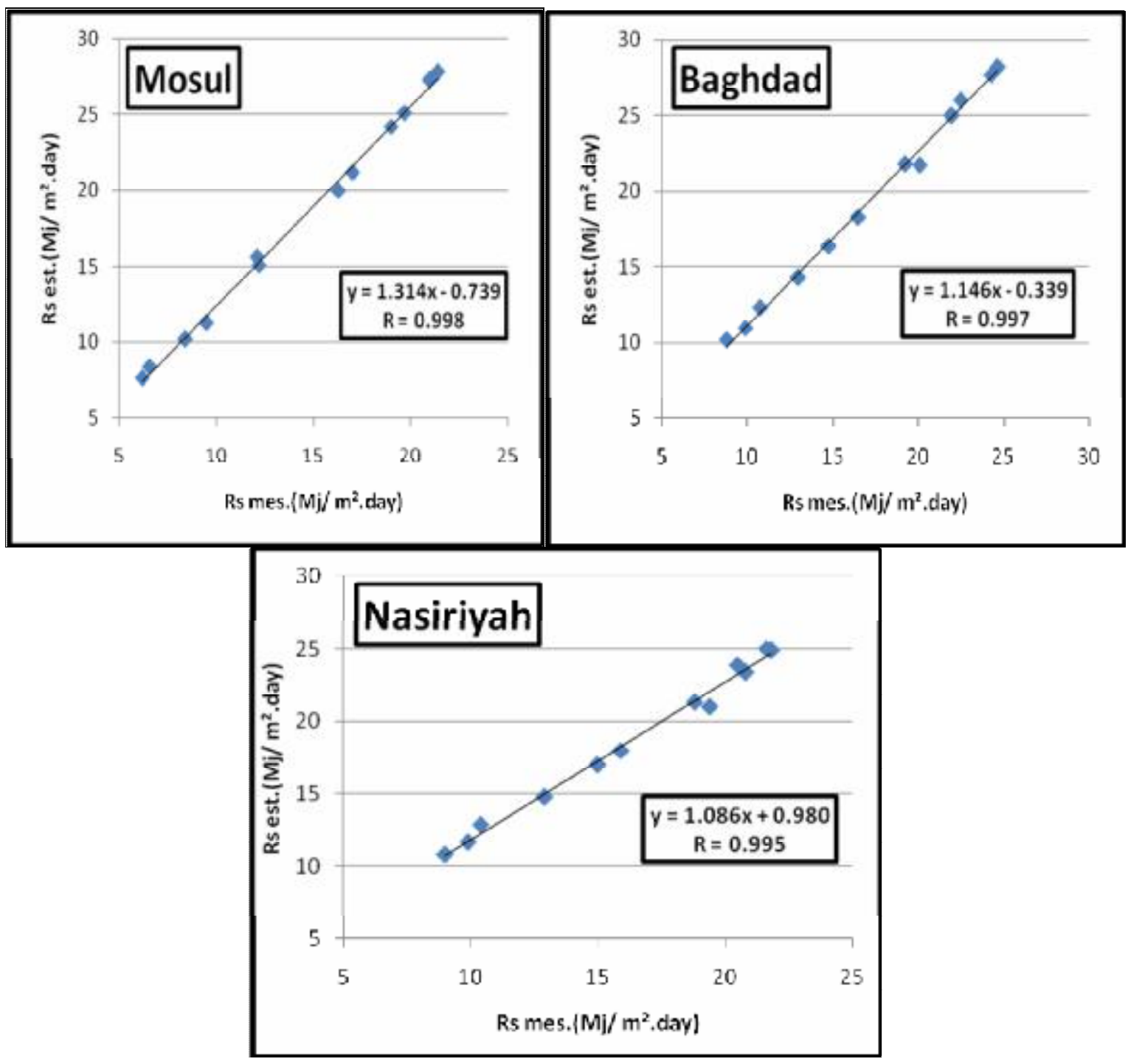

Fig 1: Correlations between estimated and measured values of Rs in Mosul, Baghdad, and Nasiriyah stations.

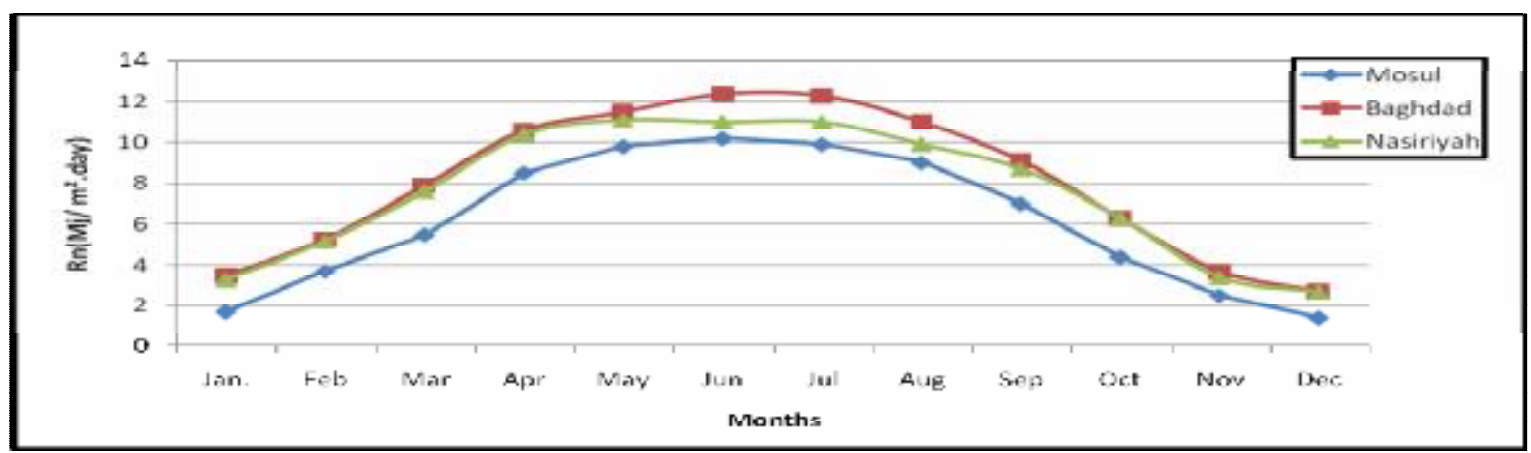

Fig 2 : Mean monthly values of net radiation in Mosul, Baghdad and Nasiriyah stations. 
Estimation of Net Radiation.........
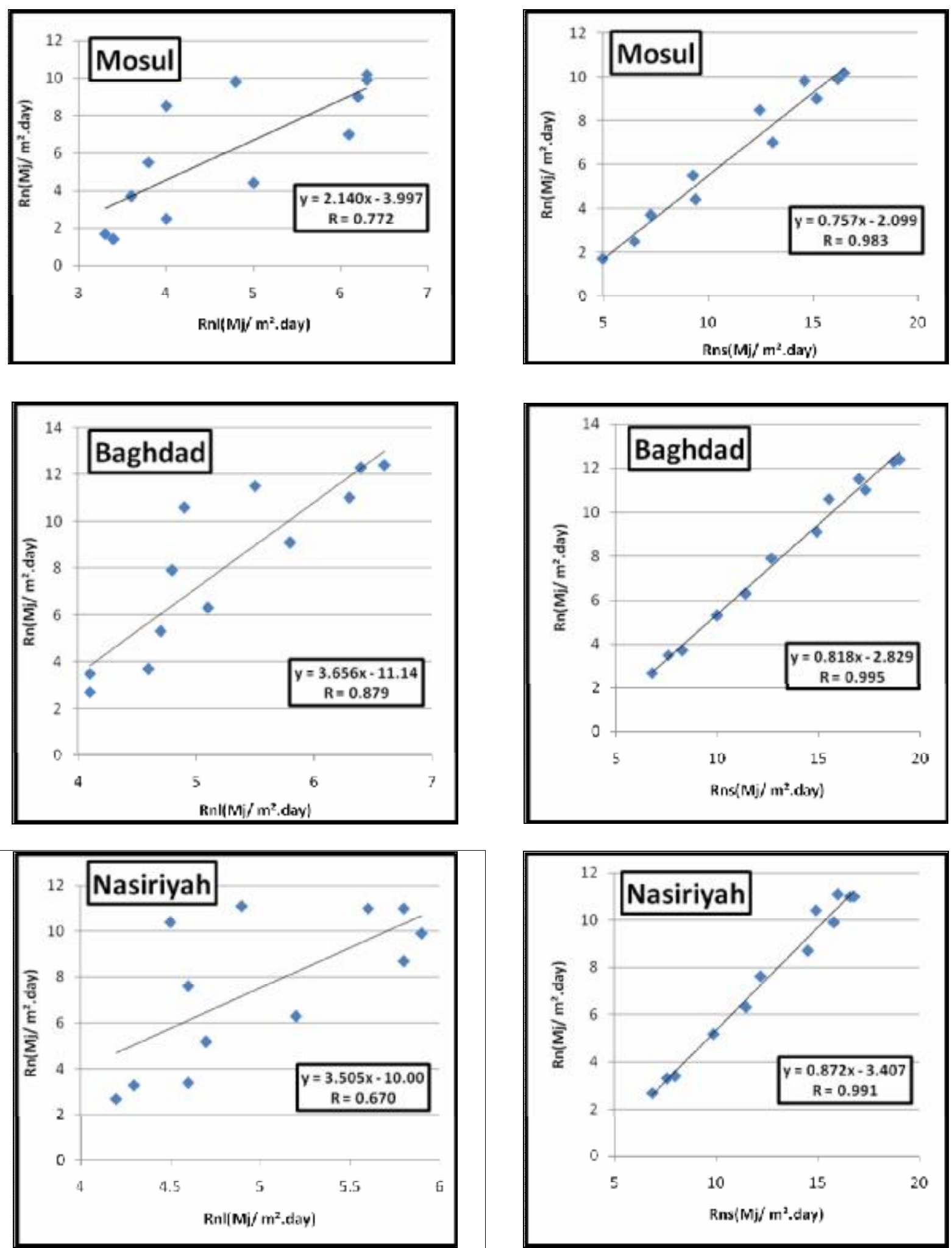

Fig 4: Correlations between $\mathrm{Rn} \& \mathrm{Rnl}$ in Mosul, Baghdad and Nasiriyah stations.

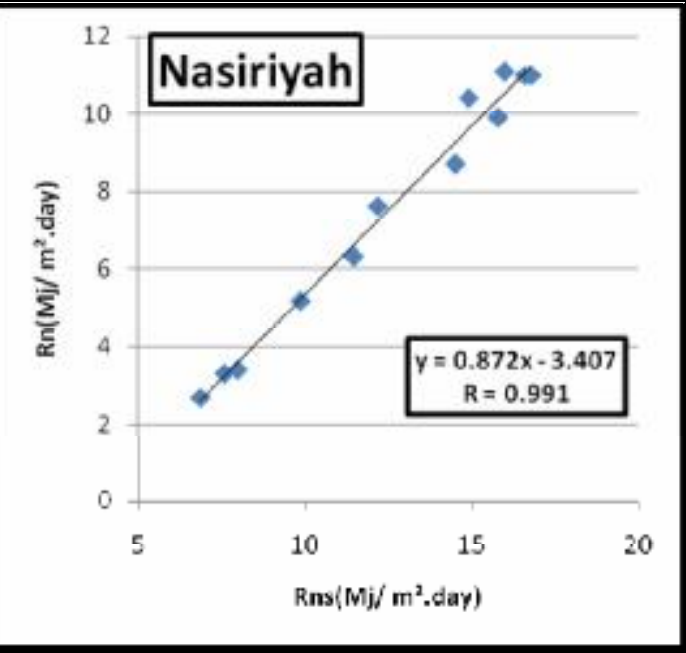

Fig 3: Correlations between Rn \& Rns in Mosul, Baghdad and Nasiriyah stations. 

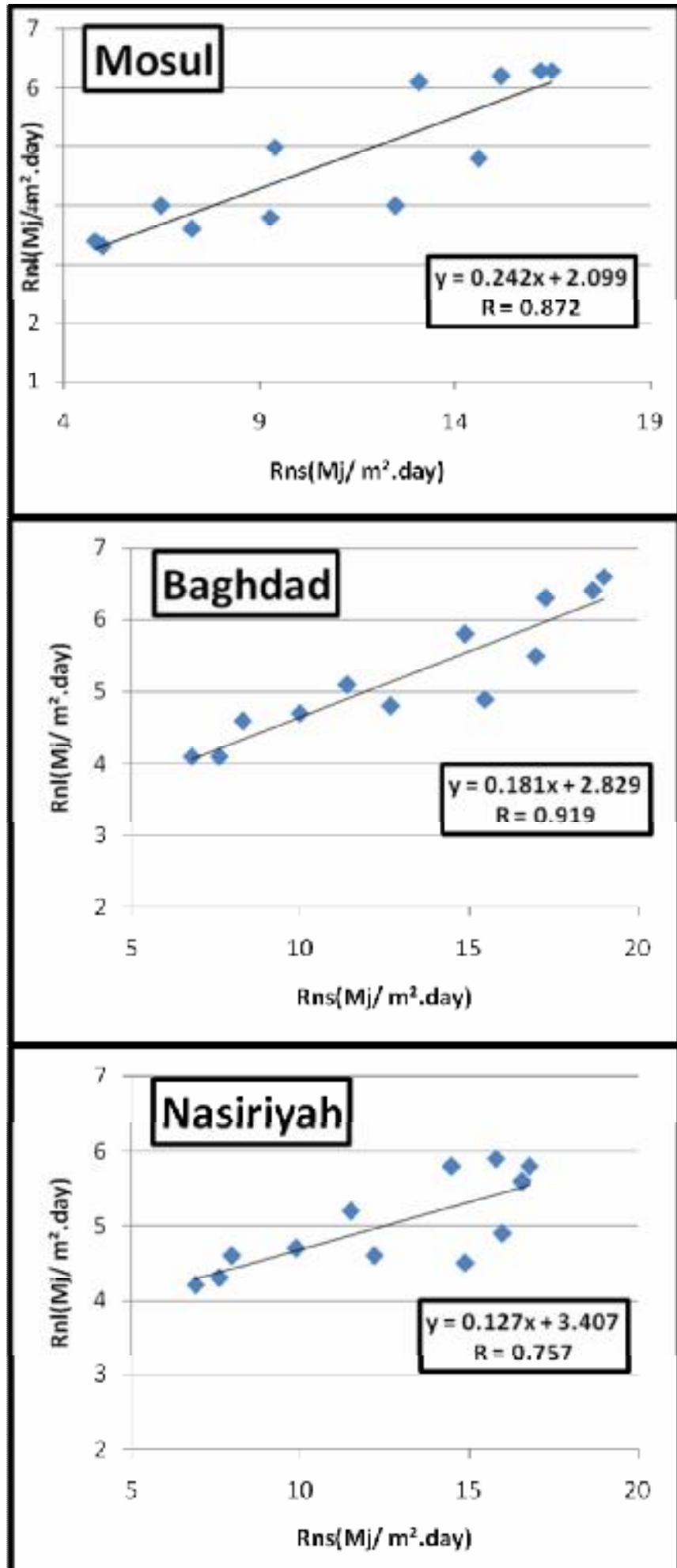

Fig 5: Correlations between Rns and Rnl in Mosul, Baghdad and Nasiriyah stations. 
Estimation of Net Radiation.........
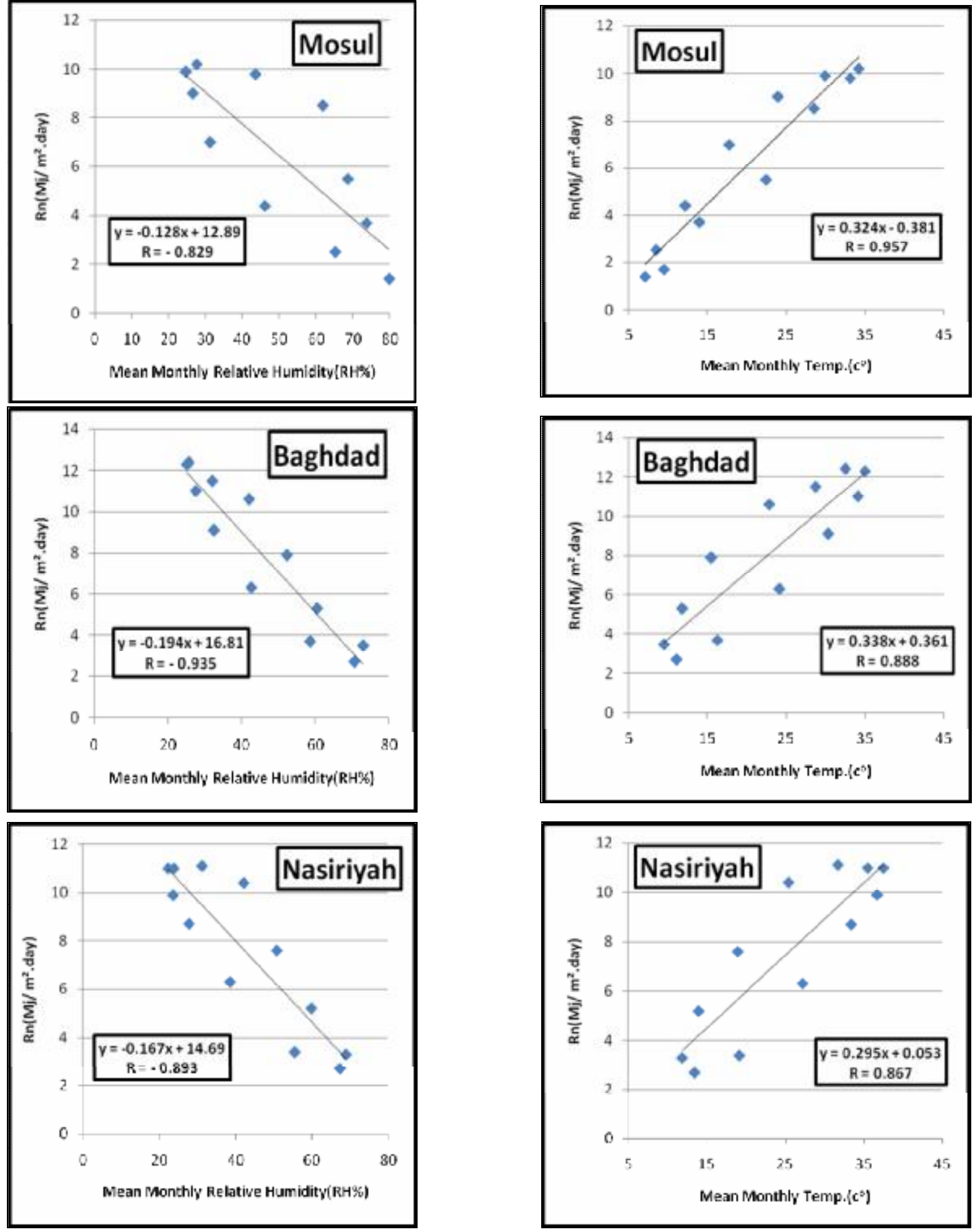

Fig 7:Correlations between $\mathrm{Rn}$ and $\mathrm{RH} \%$ in Mosul, Baghdad and Nasiriyah stations.

Fig 6:Correlations between $\mathrm{Rn}$ and Temp. in Mosul, Baghdad and Nasiriyah stations. 

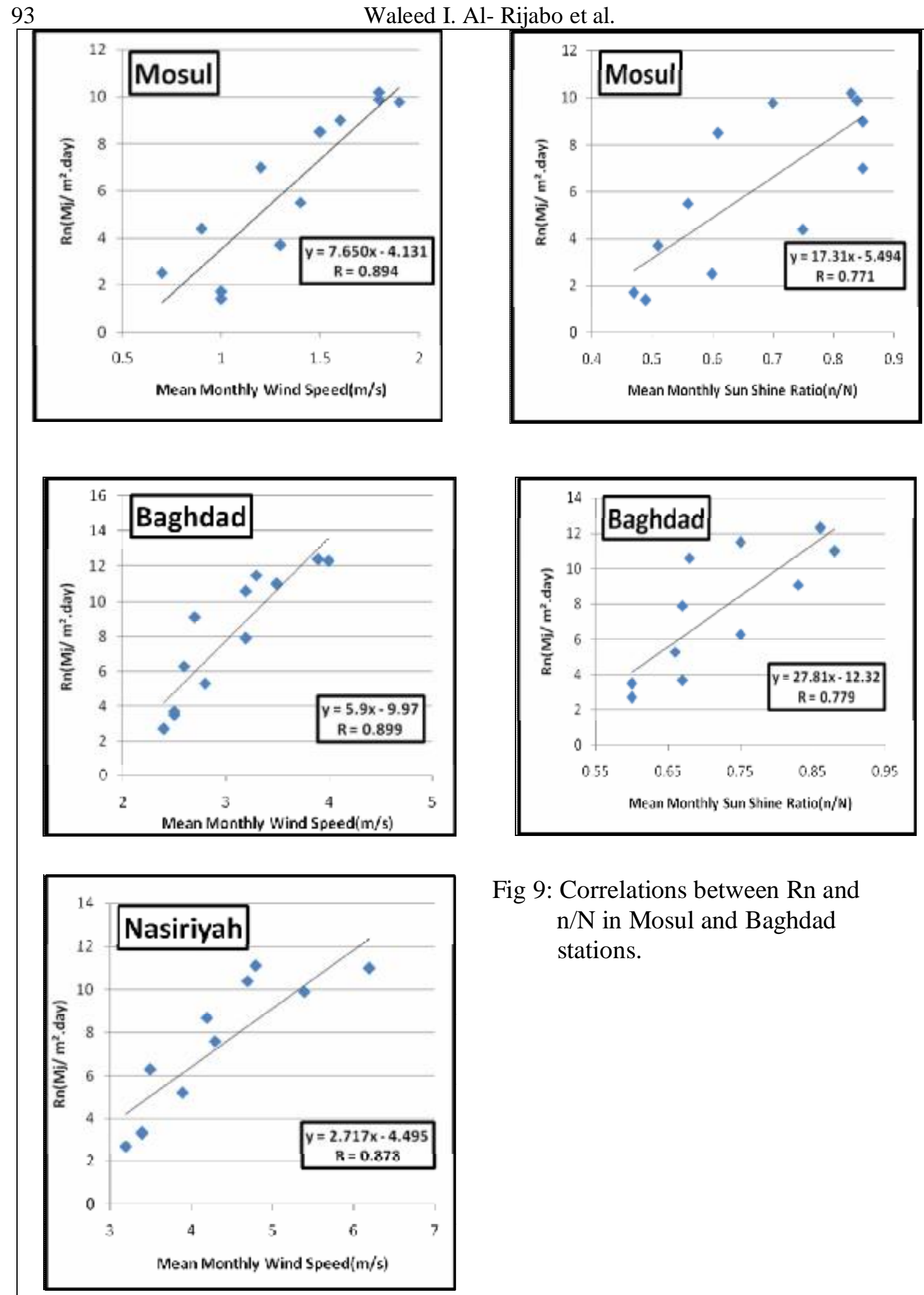

Fig 9: Correlations between Rn and $\mathrm{n} / \mathrm{N}$ in Mosul and Baghdad stations.

Fig 8 : Correlations between Rn and Wind Speed in Mosul, Baghdad and Nasiriyah Stations. 
Estimation of Net Radiation.........

Appendix 1: Mean monthly values of meteorological elements for (Mosul)station during the period (1980- 2002)

\begin{tabular}{|c|c|c|c|c|c|c|c|c|c|c|c|c|}
\hline $\begin{array}{c}\text { Months } \\
\text { Met. elements }\end{array}$ & Jan. & Feb. & Mar. & Apr. & May. & Jun. & Jul. & Aug. & Sep. & Oct. & Nov. & ec. \\
\hline $\mathrm{T} \min \left(\mathrm{c}^{\mathrm{o}}\right)$ & 2.5 & 3 & 6.3 & 10.9 & 15.8 & 21.1 & 25 & 23.9 & 18.8 & 13.3 & 7.4 & 4 \\
\hline $\mathrm{T} \max \left(\mathrm{c}^{\mathrm{o}}\right)$ & 12.4 & 14.6 & 18.9 & 25.1 & 32.7 & 39.3 & 43.2 & 42.5 & 38.1 & 30.2 & 20.9 & 13.9 \\
\hline $\mathrm{T}$ mean $\left(\mathrm{c}^{\mathrm{o}}\right)$ & 9.5 & 14 & 22.5 & 28.5 & 33.1 & 34.2 & 29.9 & 24 & 17.8 & 12.2 & 8.5 & 7.1 \\
\hline $\mathrm{RH}(\%)$ & 80.2 & 73.8 & 68.7 & 61.8 & 43.7 & 27.6 & 24.7 & 26.7 & 31.3 & 46.2 & 65.2 & 79.7 \\
\hline Wind Speed $(\mathrm{m} / \mathrm{s})$ & 1 & 1.3 & 1.4 & 1.5 & 1.9 & 1.8 & 1.8 & 1.6 & 1.2 & 0.9 & 0.7 & 1 \\
\hline Rs $\left(\mathrm{Mj} / \mathrm{m}^{2}\right.$.day $)$ & 6.6 & 9.5 & 12.1 & 16.3 & 19 & 21.4 & 21 & 19.7 & 17 & 12.2 & 8.4 & 6.2 \\
\hline n (hrs) & 4.6 & 5.5 & 6.6 & 8 & 9.9 & 12 & 12 & 11.4 & 10.4 & 8.2 & 6 & 4.7 \\
\hline $\mathrm{N}(\mathrm{hrs})$ & 9.8 & 10.4 & 11.8 & 13 & 14 & 14.5 & 14.2 & 13.3 & 12.2 & 11 & 10 & 9.5 \\
\hline $\mathrm{n} / \mathrm{N}$ & 0.47 & 0.51 & 0.56 & 0.61 & 0.70 & 0.83 & 0.84 & 0.85 & 0.85 & 0.75 & 0.60 & 0.49 \\
\hline
\end{tabular}

Appendix 2: Mean monthly values of meteorological elements for (Baghdad) station during the period (1980- 2002)

\begin{tabular}{|c|c|c|c|c|c|c|c|c|c|c|c|c|}
\hline $\begin{array}{c}\text { Months } \\
\text { Met. elements }\end{array}$ & Jan. & Feb. & Mar. & Apr. & May. & Jun. & Jul. & Aug. & Sep. & Oct. & Nov. & Dec. \\
\hline $\mathrm{T} \min \left(\mathrm{c}^{\mathrm{o}}\right)$ & 4.2 & 5,6 & 9,7 & 15.4 & 20,2 & 23,4 & 25,8 & 24,7 & 20.7 & 69.7 & 9.8 & 5.4 \\
\hline $\mathrm{T} \max \left(\mathrm{c}^{\mathrm{o}}\right)$ & 15.7 & 18.4 & 22.6 & 30.1 & 36.5 & 41.3 & 44.2 & 42.9 & 40 & 33.1 & 23.6 & 17.4 \\
\hline $\mathrm{T}$ mean $\left(\mathrm{c}^{\mathrm{o}}\right)$ & 9.5 & 11.8 & 15.5 & 22.9 & 28.7 & 32.5 & 35 & 34.1 & 30.3 & 24.2 & 16.3 & 11.1 \\
\hline $\mathrm{RH}(\%)$ & 73 & 60.5 & 52.3 & 42 & 32 & 25.6 & 25.1 & 27.5 & 32.4 & 42.6 & 58.6 & 70.6 \\
\hline Wind Speed $(\mathrm{m} / \mathrm{s})$ & 2.5 & 2.8 & 3.2 & 3.2 & 3.3 & 3.9 & 4 & 3.5 & 2.7 & 2.6 & 2.5 & 2.4 \\
\hline $\operatorname{Rs}\left(\mathrm{Mj} / \mathrm{m}^{2}\right.$.day $)$ & 9.9 & 13 & 16.5 & 20.1 & 22 & 24.7 & 24.3 & 22.5 & 19.3 & 14.8 & 10.8 & 8.8 \\
\hline n (hrs) & 6.1 & 7.2 & 8.0 & 8.8 & 10.2 & 12.2 & 12 & 11.6 & 10.2 & 8.4 & 6.8 & 6 \\
\hline $\mathrm{N}$ (hrs) & 10.1 & 10.8 & 11.8 & 12.8 & 13.7 & 14.1 & 13.9 & 13.2 & 12.2 & 11.2 & 10.3 & 9.9 \\
\hline $\mathrm{n} / \mathrm{N}$ & 0.6 & 0.66 & 0.67 & 0.68 & 0.75 & 0.86 & 0.86 & 0.88 & 0.83 & 0.75 & 0.67 & 0.6 \\
\hline
\end{tabular}

Appendix 3 : Mean monthly values of meteorological elements for (Nasiriyah) station during the period (1980-2002)

\begin{tabular}{|c|c|c|c|c|c|c|c|c|c|c|c|c|}
\hline $\begin{array}{c}\text { Months } \\
\text { Met. elements } \\
\end{array}$ & Jan. & Feb. & Mar. & Apr. & May. & Jun. & Jul. & Aug. & Sep. & Oct. & Nov. & Dec. \\
\hline $\mathrm{T} \min \left(\mathrm{c}^{\mathrm{o}}\right)$ & 6.4 & 8 & 12.4 & 18.7 & 23.6 & 26.3 & 28.3 & 27.6 & 24.3 & 19.3 & 12.8 & 7.7 \\
\hline $\mathrm{T} \max \left(\mathrm{c}^{\mathrm{o}}\right)$ & 17.3 & 20 & 25.2 & 31.8 & 38.7 & 43 & 45.2 & 45 & 42 & 35.4 & 26 & 19.4 \\
\hline $\mathrm{T}$ mean $\left(\mathrm{c}^{\mathrm{o}}\right)$ & 11.9 & 14 & 19 & 25.4 & 31.7 & 35.5 & 37.5 & 36.7 & 33.4 & 27.2 & 19.2 & 13.5 \\
\hline $\mathrm{RH}(\%)$ & 69.1 & 60 & 50.9 & 42.2 & 31.2 & 23.8 & 22.3 & 23.6 & 27.8 & 38.6 & 55.6 & 67.4 \\
\hline Wind speed $(\mathrm{m} / \mathrm{s})$ & 3.4 & 3.9 & 4.3 & 4.7 & 4.8 & 6.2 & 6.2 & 5.4 & 4.2 & 3.5 & 3.4 & 3.2 \\
\hline $\operatorname{Rs}\left(\mathrm{Mj} / \mathrm{m}^{2}\right.$.day $)$ & 9.9 & 12.9 & 15.9 & 19.4 & 20.8 & 21.6 & 21.8 & 20.5 & 18.8 & 15 & 10.4 & 9 \\
\hline $\mathrm{n}$ (hrs) & 6.5 & 7.4 & 7.6 & 8.2 & 9 & 9.2 & 10 & 10 & 9.6 & 8.5 & 7.2 & 6.3 \\
\hline $\mathrm{N}(\mathrm{hrs})$ & 10.9 & 10.9 & 11.6 & 12.8 & 13.6 & 14 & 13.8 & 13.1 & 12.1 & 11.2 & 10.4 & 10 \\
\hline $\mathrm{n} / \mathrm{N}$ & 0.64 & 0.67 & 0.64 & 0.64 & 0.66 & 0.70 & 0.72 & 0.76 & 0.79 & 0.76 & 0.69 & 0.62 \\
\hline
\end{tabular}


Appendix (4) : Mean monthly values of radiation elements in( Mosul) city during the period (1980-2002)

\begin{tabular}{|c|c|c|c|c|c|c|c|c|c|c|c|c|}
\hline Months & & & & & & & & & & & & \\
\hline $\begin{array}{l}\text { Radiation } \\
\text { elements }\end{array}$ & Jan. & Feb. & Mar. & Apr. & May. & Jun. & Jul. & Aug. & Sep. & Oct. & Nov. & Dec. \\
\hline $\begin{array}{l}\mathrm{RA}(\mathrm{Mj} / \\
\left.\mathrm{m}^{2} . \text { day }\right)\end{array}$ & 17.3 & 22.3 & 29.4 & 35.8 & 40.1 & 41.7 & 40.8 & 37.1 & 31.3 & 24.2 & 18.5 & 15.9 \\
\hline $\begin{array}{l}\mathrm{RS}((\mathrm{Mj} / \\
\left.\mathrm{m}^{2} . \text { day }\right)\end{array}$ & 6.6 & 9.5 & 12.1 & 16.3 & 19 & 21.4 & 21 & 19.7 & 17 & 12.2 & 8.4 & 6.2 \\
\hline $\begin{array}{l}\mathrm{RSO}(\mathrm{Mj} / \\
\mathrm{m}^{2} \text {.day) }\end{array}$ & 13 & 16.8 & 22.1 & 27 & 30.3 & 31.5 & 30.7 & 28 & 23.6 & 18.3 & 14 & 12 \\
\hline $\begin{array}{l}\text { Rns(Mj/ } \\
\text { m².day) }^{2}\end{array}$ & 5 & 7.3 & 9.3 & 12.5 & 14.6 & 16.5 & 16.2 & 15.2 & 13.1 & 9.4 & 6.5 & 4.8 \\
\hline $\begin{array}{l}\text { Rnl(Mj/ } \\
\mathrm{m}^{2} \text {.day) }\end{array}$ & 3.3 & 3.6 & 3.8 & 4 & 4.8 & 6.3 & 6.3 & 6.2 & 6.1 & 5 & 4 & 3.4 \\
\hline $\begin{array}{l}\mathrm{Rn}(\mathrm{Mj} / \\
\mathrm{m}^{2} \text {.day) }\end{array}$ & 1.7 & 3.7 & 5.5 & 8.5 & 9.8 & 10.2 & 9.9 & 9 & 7 & 4.4 & 2.5 & 1.4 \\
\hline
\end{tabular}

Appendix 5: Mean monthly values of radiation elements in( Baghdad) city during the period(19802002)

\begin{tabular}{|c|c|c|c|c|c|c|c|c|c|c|c|c|}
\hline Months & & & & & & & & & & & & \\
\hline $\begin{array}{l}\text { Radiation } \\
\text { elements }\end{array}$ & Jan. & Feb. & Mar. & Apr. & May. & Jun. & Jul. & Aug. & Sep. & Oct. & Nov. & Dec. \\
\hline $\begin{array}{l}\mathrm{RA}(\mathrm{Mj} / \\
\left.\mathrm{m}^{2} . \text { day }\right)\end{array}$ & 19.8 & 24.5 & 31 & 36.6 & 40.2 & 41.4 & 40.6 & 37.7 & 32.7 & 26.3 & 20.9 & 18.4 \\
\hline $\begin{array}{l}\mathrm{RS}((\mathrm{Mj} / \\
\left.\mathrm{m}^{2} . \text { day }\right)\end{array}$ & 9.9 & 13 & 16.5 & 20.1 & 22 & 24.7 & 24.3 & 22.5 & 19.3 & 14.8 & 10.8 & 8.8 \\
\hline $\begin{array}{c}\mathrm{RSO}(\mathrm{Mj} / \\
\mathrm{m}^{2} \text {.day) }\end{array}$ & 14.8 & 18.4 & 23.3 & 27.5 & 30.2 & 31 & 30.5 & 28.3 & 24.5 & 19.7 & 15.7 & 13.8 \\
\hline $\begin{array}{l}\text { Rns(Mj/ } \\
m^{2} \text {.day) }\end{array}$ & 7.6 & 10 & 12.7 & 15.5 & 17 & 19 & 18.7 & 17.3 & 14.9 & 11.4 & 8.3 & 6.8 \\
\hline $\begin{array}{l}\mathrm{Rnl}(\mathrm{Mj} / \\
\mathrm{m}^{2} \text {.day) }\end{array}$ & 4.1 & 4.7 & 4.8 & 4.9 & 5.5 & 6.6 & 6.4 & 6.3 & 5.8 & 5.1 & 4.6 & 4.1 \\
\hline $\begin{array}{l}\mathrm{Rn}(\mathrm{Mj} / \\
\left.\mathrm{m}^{2} \text {.day }\right)\end{array}$ & 3.5 & 5.3 & 7.9 & 10.6 & 11.5 & 12.4 & 12.3 & 11 & 9.1 & 6.3 & 3.7 & 2.7 \\
\hline
\end{tabular}

Appendix 6: Mean monthly values of radiation elements in( Nasiriyah) city during the period(19801991)

\begin{tabular}{|c|c|c|c|c|c|c|c|c|c|c|c|c|}
\hline Months & & & & & & & & & & & & \\
\hline $\begin{array}{c}\text { Radiation } \\
\text { elements }\end{array}$ & Jan. & Feb. & Mar. & Apr. & May. & Jun. & Jul. & Aug. & Sep. & Oct. & Nov. & Dec. \\
\hline $\mathrm{RA}\left(\mathrm{Mj} / \mathrm{m}^{2}\right.$.day $)$ & 20.4 & 25 & 31.4 & 36.8 & 40.2 & 41.3 & 40.6 & 37.8 & 33 & 26.8 & 21.6 & 19.1 \\
\hline $\mathrm{RS}\left(\left(\mathrm{Mj} / \mathrm{m}^{2}\right.\right.$.day $)$ & 9.9 & 12.9 & 15.9 & 19.4 & 20.8 & 21.6 & 21.8 & 20.5 & 18.8 & 15 & 10.4 & 9 \\
\hline $\mathrm{RSO}\left(\mathrm{Mj} / \mathrm{m}^{2}\right.$.day $)$ & 15.3 & 18.8 & 23.6 & 27.6 & 30.1 & 31 & 30.4 & 28.3 & 24.8 & 20.1 & 16.2 & 14.3 \\
\hline Rns(Mj/ m².day) & 7.6 & 9.9 & 12.2 & 14.9 & 16 & 16.6 & 16.8 & 15.8 & 14.5 & 11.5 & 8 & 6.9 \\
\hline Rnl(Mj/ m².day) & 4.3 & 4.7 & 4.6 & 4.5 & 4.9 & 5.6 & 5.8 & 5.9 & 5.8 & 5.2 & 4.6 & 4.2 \\
\hline $\mathrm{Rn}\left(\mathrm{Mj} / \mathrm{m}^{2}\right.$.day $)$ & 3.3 & 5.2 & 7.6 & 10.4 & 11.1 & 11 & 11 & 9.9 & 8.7 & 6.3 & 3.4 & 2.7 \\
\hline
\end{tabular}

